\title{
A LÉT MAGYAR HÁZA
}

Fontos könyvet jelentetett meg fontos problémákról Kontra Miklós, akit sosem lehetett azzal vádolni, hogy a tudomány elefántcsonttornyából szemléli közömbösen a világot, ha egyáltalán kinéz a torony valamelyik ablakán. Már a könyv címe, Felelös nyelvészet is utal az attitüdre, amelyben az igazság keresése nemhogy kizárná, hanem egyenesen feltételezi a szenvedélyt, mely az igazság érvényesítésére, elismertetésére hajtja a tudóst.

A könyv az elmúlt években keletkezett, nyolc fejezetbe csoportosított tizenhét kis írást tartalmaz, melyek kisebb részét egy gondosabb szerkesztő rövidségük, alkalomhoz kötöttségük okán kirostálhatta volna.

A könyv témája, Kontra imponáló szakmai életútja ismeretében nem meglepően, a nyelv és különösen a magyar nyelv élete, helye, müködése a társadalomban. A nyelv egyetemes világa természetesen a Kontra által vizsgált körnél jóval tágasabb. A nyelv által válik belsővé az emberekben a külső végtelenség, elgondolhatóvá, átérezhetővé és közölhetővé téve számukra a lét igazságait és nyugtalanító rejtélyeit. Kontra Miklós nyelvinterpretációja nem megy a lét eredendő lényegszerkezete felé vezetö filozófiai úton, hanem megmarad a nyelv hagyományos nyelvészetfelfogásán belül, melyet azonban társadalmi kontextusba helyezve egyúttal meg is halad.

A könyv írásainak egyik fókusza a nyelvpedagógia, másik fókusza a nyelv és hatalom, a nyelvpolitika.

Terestyéni Tamás kutatásaiból tudjuk, hogy a magyar társadalom tagjai idegennyelv-tudásának szintje szívszomorítóan alacsony. A megoldást az idegen nyelvek elsajátíttatása jelenthetné, kezdve a lehető legkorábbi gyermekkorban, beleértve a kétnyelvü iskolai oktatást, az idegen nyelven beszélő filmek magyar nyelvre történő szinkronizálásának elhagyását, a kulturális, politikai és gazdasági elit példamutatását. Kontra Miklósnak Medgyes Péterrel együtt elévülhetetlen érdemei vannak az egyetemi szintủ angoltanári képzés megújitásában, a humboldti hagyomány lebontásában, mely a leendő angoltanárok képzése során a nyelvészetet a didaktika kárára előnyben részesítette. A Kontra által elbeszélt történetnek nincs happy endje. A kezdeti sikerek után a reform megtört a humboldtiánus elvek képviselöinek ellenállásán, a CETT (Centres for English Teacher Training) által inspirált programok kiszorultak a tanárképzésböl. Kontra idézi Medgyes Pétert, aki az egyetemi angol tanárképzés sorsát keserúen a balladai Déva várához hasonlítja: ,amit reggel raktak, estére leomlott. Amit este raktak, reggelre leomlott" (76.).

A nyelvpolitika a nyelv társadalomban betöltött szerepét teljesen félreértve a nyelvet a politikai akarat által tetszés szerint felhasználható hatalmi eszköznek tekinti. 
Johann Gottfried Herder kétszázötven évvel ezelött elhangzott nevezetes jóslata szerint „a magyarok mint az ország lakosainak legcsekélyebb része, most szlávok, németek, románok és más népek közé vannak beékelve, s századok múltán talán nyelvüket is alig lehet felfedezni”. Kontra adatolva teszi világossá, hogy bár a magyar nyelv kihalásától való félelem alaptalan, a trianoni, majd párizsi békék eredményeként a Magyarországgal határos országokban kisebbségbe került magyar anyanyelvủek körében a magyar nyelv eltünésének veszélye nagyon is reális. Esettanulmányokkal mutatja be a többségi nemzet nyelvét tüzzel-vassal terjesztő állam által kikényszerített nyelvvesztés folyamatát, melynek minősítésére a „nyelvi genocídium” kifejezést sem tartja súlyosnak. Más esetekben a nyelvvesztés nem kényszer, hanem önkéntes asszimiláció eredménye. A kétnyelvüség lenne a megoldás, de csak abban az esetben, ha az egyik nyelv nem rendelődik alá a másik nyelvnek, az anyanyelv és az állam által favorizált nyelv egyenrangú.

Kontra sokfejű sárkánya, mellyel szemben Szent Györgyként küzd, a lingvicizmus, mely alatt a nyelvet ürügyként használó tudatlan és arrogáns hatalmi viszszaéléseket érti. Példái akár nevettetőek is lehetnének, ha nem tudnánk, hogy vakvágányra juttatott emberi életek, megnyomorított sorsok vannak mögöttük. Egyik írásában beszámol a budapesti székhelyü Nemzetstratégiai Kutatóintézet Nemzetstratégiai Akadémiája által 2014 márciusában rendezett konferenciáról, amelynek résztvevői a „kisebbség” szó kiiktatásának lehetőségeit vitatták meg, nem számolván azzal, hogy e szó nélkül számos történeti, jogi és politikai szöveg érthetetlenné válna.

A nyelvpolitikai megszállottság azonban távolról sem csupán a kelet-középeurópai nemzeti lét nyomorúsága. Szívesen olvastunk volna olyan írásokat a témában, melyek a politikai korrektség jegyében a mindennapi nyelvhasználatot fenekestül felforgató ultraliberális nyelvpolitika túlzásairól számoltak volna be, nem riadva vissza akár a Biblia átírásától sem.

A könyv egyik legtanulságosabb, s egyben igen szórakoztató esetét az F. Dornbach Máriával együtt írt Falusi történet címü írása beszéli el. Az eset Gazdag Gyula korai dokumentumfilmjeire emlékeztetően a Szigetújfalu polgármestere által gyakorolt nyelvi önkényt mutatja be, mellyel a polgármester a korábban használatos szigetujfalusi jelzőt az általa preferált szigetujfalui jelzőre íratta át. A harc a kétféle írásmód között mind a mai napig tart, jól mutatva a nyelv és az identitás közötti szoros kapcsolatot, amit Madách Imre oly érzékletesen mutatott be az Ember tragédiája bizánci színének Homousion és Homoiusion vitájában.

Kontra sárkányának fejei közé tartozik a magyar nyelv helyesírási kánonja, melynek folyamatos változtatására soha senki semmilyen épeszủ indokot nem tudott felhozni. Miért kell két szóban írnunk azt, hogy „,vajas kenyér”, szemben az egy szóban írandó „zsíroskenyérrel”? Miért kell olyan szabályokat megállapítani, melyeket a magyarul írni és olvasni tudók többsége nem tart be, részint mert 
nem is ismeri azokat, részint mert nem tartja fontosnak azok betartását? Ezekre a kérdésekre nincs, mert nem is lehet választ adni.

Kontra Miklós nyelvpolitikai írásaiból kiderül, hogy a gordiuszi csomók java része átvághatóvá válna, ha az alapvető emberi jogok katalógusába nevesítve bekerülne az anyanyelvhez való jog, amelybe beletartozik az anyanyelvi iskolázás, a művelödés, a hatóságokkal való kommunikáció joga, ahogyan azt a könyvben sokszor idézett neves erdélyi nyelvtudós, Szilágyi N. Sándor 1994-ben a Korunk március számában közzétett törvénytervezetében megfogalmazta. A törvénytervezet azonban pusztába kiáltott szó maradt.

Martin Heidegger helyesen mondja, hogy a „nyelv a lét háza”. Tudnunk kell azonban, hogy e házban annyi lakás van, ahány nyelven beszélnek lakói. Kontra Miklós könyve a nyelv magyar lakásában élők felelősségére figyelmeztet.

(Kontra Miklós: Felelös nyelvészet. Budapest: Gondolat Kiadó, 2019, 264 o.)

Csepeli György

szociológus Eötvös Loránd Tudományegyetem Társadalomtudományi Kar 